\title{
PREDIKSI KEBANGKRUTAN DENGAN METODE ALTMAN Z-SCORE, SPRINGATE DAN ZMIJEWSKI PADA PERUSAHAAN DELISTING DI BURSA EFEK INDONESIA (BEI)
}

\author{
Anggita Prameswari \\ anggita1010@gmail.com \\ Irni Yunita \\ Muhammad Azhari
}

Fakultas Ekonomi dan Bisnis, Universitas Telkom

diterima: 18/4/2017; direvisi: 10/5/2017; diterbitkan: 27/4/2018

\begin{abstract}
This research aimed to understand how to use of the Altman Z-Score, Springate, and Zmijewski methods, to predict bankruptcy and help to analyze companies that have been delisted from Indonesian Stock Exchange in time period of 2011-2015. This research used descriptive method with quantitative approach. The population used in this research are companies that have been delisted in time period of 2011-2015, using the financial report from three years before the companies delisting from Indonesian Stock Exchange. Non-probability sampling with purposive sampling technique were used, with nine companies that have been delisted from Indonesian Stock Exchange. The result showed that there are different prediction from each methods. Most delisting companies are predicted to bankrupt at least one of the methods.
\end{abstract}

Keywords: bankruptcy; Altman Z-Score method; Springate method; Zmijewski method; delisting

\begin{abstract}
Abstrak
Penelitian ini bertujuan untuk mengetahui bagaimana prediksi kebangkrutan dengan menggunakan metode Altman Z-Score, Springate dan Zmijewski dalam menganalisis perusahaan yang telah delisting di Bursa Efek Indonesia periode 2011-2015. Jenis metode yang digunakan di dalam penelitian ini menggunakan metode deskriptif dengan pendekatan kuantitatif. Populasi yang digunakan dalam penelitian ini yaitu perusahaan yang telah delisting di Bursa Efek Indonesia pada tahun 2011-2015, dengan menggunakan pendekatan studi laporan keuangan tiga tahun sebelum perusahaan delisting. Teknik pengambilan sampel menggunakan purposive sampling sebanyak sembilan perusahaan delisting pada Bursa Efek Indonesia. Hasil penelitian menunjukkan adanya perbedaan prediksi dari masing-masing metode. Kebanyakan perusahaan yang delisting diprediksi bangkrut sedikitnya dari salah satu metode.
\end{abstract}

Kata Kunci : kebangkrutan; metode Altman Z-Score; metode Springate; metode Zmijewski; delisting 


\section{PENDAHULUAN}

Setiap perusahaan pada umumnya memiliki tujuan untuk mendapatkan keuntungan, sehingga perusahaan membutuhkan modal atau pendanaan sebagai dasar untuk melakukan kegiatannya. Dalam mencapai tujuan agar terus tumbuh dan berkembang pesat, perusahaan dapat memanfaatkan keberadaan pasar modal sebagai sarana transaksi jual beli saham untuk meningkatkan nilai perusahaan dan mendapatkan sumber dana yang relatif besar.

Perusahaan dapat melakukan penjualan saham melalui Bursa Efek Indonesia dengan mendaftarkan terlebih dahulu sebagai perusahaan go public. Go public adalah kegiatan penawaran saham atau efek lainnya yang dilakukan oleh emiten (perusahaan) untuk menjual saham atau efek kepada masyarakat berdasarkan tata cara yang diatur oleh UU Pasar Modal dan Peraturan Pelaksanaannya.

Saham yang sudah tercatat di Bursa dapat diperjualbelikan kepada investor di pasar modal. Adanya pasar modal dapat dijadikan sebagai alat untuk merefleksikan kinerja dan kondisi keuangan perusahaan. Pasar akan merespon positif melalui peningkatan harga saham perusahaan jika kondisi keuangan dan kinerja perusahaan bagus. Oleh karena itu, analisis dan prediksi atas kondisi keuangan suatu perusahaan adalah sangat penting.

Kasus delisting yang pernah terjadi di Bursa Efek Indonesia (BEI) yang menyatakan terdapat dua puluh perusahaan emiten pada lima tahun terakhir yang telah dihapus pencatatan sahamnya (delisting) dari Bursa Efek Indonesia. Langkah tersebut adalah langkah wajib yang harus diambil otoritas bursa untuk melindungi potensi timbulnya kerugian, baik di sisi investor maupun perusahaan itu sendiri.

Delisting terjadi apabila saham yang tercatat di Bursa mengalami penurunan kriteria sehingga tidak memenuhi persyaratan pencatatan, maka saham tersebut dapat dikeluarkan dari pencatatan di Bursa Efek Indonesia. Setelah sebuah perusahaan dikeluarkan dari bursa, maka semua kewajiban yang semula melekat akan ikut terhapus, termasuk kewajiban untuk menerbitkan laporan keuangan. Delisting dapat dilakukan atas permintaan perusahaan yang menerbitkan saham maupun atas perintah BEI.

Gambar 1 terlihat fenomena selama lima tahun terakhir, Bursa Efek Indonesia (BEI) sudah menghapus dua puluh saham perusahaan tercatat. Adapun acuan yang dipakai oleh BEI dalam menghapus saham perusahaan tercatat yaitu Peraturan Bursa Nomor I-I tentang Penghapusan Pencatatan (Delisting) dan Pencatatan Kembali (Relisting) Saham di Bursa Ketentuan III.3.I.I. Dalam Peraturan tersebut disebutkan bahwa BEI menghapus pencatatan saham perusahaan tercatat apabila perusahaan tercatat mengalami sekurang-kurangnya satu kondisi atau peristiwa, yang secara signifikan berpengaruh

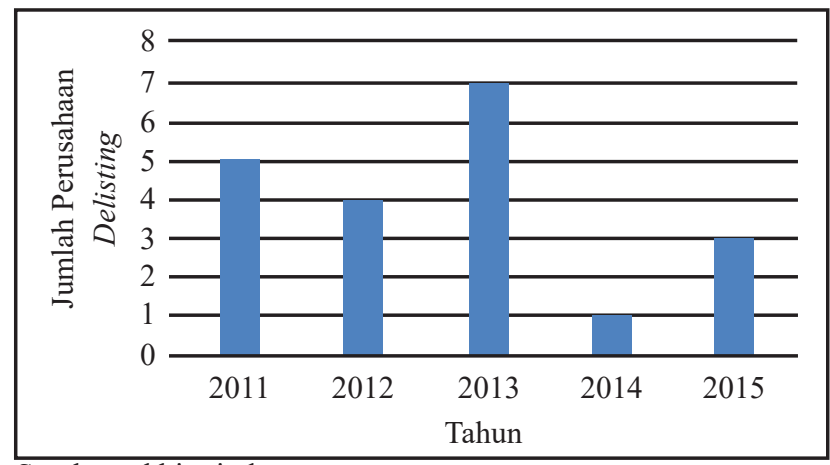

Sumber: ekbis.sindonews.com

Gambar 1. Grafik Data Perusahaan yang delisting di Bursa Efek Indonesia tahun $2011-2015$

negatif terhadap kelangsungan usaha perusahaan tercatat sebagai perusahaan terbuka. Selain itu, perusahaan tercatat tidak dapat menunjukan indikasi pemulihan yang memadai. Untuk menanggulangi fenomena tersebut, sebaiknya perusahaan melakukan analisis kebangkrutan yang melihat dari segi rasio keuangan perusahaan yang terdapat di laporan keuangan.

Penelitian mengenai analisis kebangkrutan suatu perusahaan telah banyak dilakukan di Indonesia, akan tetapi penelitian mengenai analisis kebangkrutan perusahaan delisting dengan perbandingan modelmodel prediksi kebangkrutan masih jarang. Analisis kebangkrutan yang sering digunakan adalah metode Altman Z-Score, Springate dan Zmijewski. Alasan ketiga metode tersebut digunakan karena memiliki tingkat keakuratan yang cukup tinggi. Metode Altman Z-Score memiliki tingkat keakurat 95\%. Model Springate membedakan perusahaan yang berada dalam zona bangkrut atau zona sehat. Metode Springate memiliki tingkat keakuratan 92,5\%. Sedangkan metode Zmijewski membedakan perusahaan yang berpotensi mengalami kebangkrutan atau jauh dari potensi mengalami kebangkrutan. Tingkat akurasi dari metode Zmijewski ini adalah sebesar 94,9\%.

Altman (1968) menggunakan metode Multiple Discriminant Analysis dan terdapat beberapa metode Altman Z-Score dengan perhitungan yang berbedabeda dalam menganalisis kebangkrutan perusahaan yang dikategorikan ke dalam beberapa jenis industri. Springate (1978) dikembangkan oleh Gorgon L.V. Springate. Metode Springate menggunakan Multiple Discriminant Analysis (MDA) untuk memilih empat dari 19 rasio keuangan yang popular sehingga dapat membedakan perusahaan yang berada dalam zona bangkrut atau zona aman. Zmijewski (1984) yang dikembangkan oleh Zmijewski dengan menggunakan analisis rasio yang mengukur kinerja, leverage, dan likuiditas suatu perusahaan untuk model prediksinya.

Setelah dilakukan perhitungan berdasarkan model kebangkrutan, skor yang didapat kemudian dibandingkan dengan cut off yang dimiliki setiap model, dari hasil perbandingan tersebut diperoleh apakah 
diprediksi berpotensi mengalami bangkrut atau tidak bangkrut. Dari ketiga metode akan dilakukan analisis untuk dapat mengetahui ketiga metode tersebut dalam menganalisis kebangkrutan pada perusahaan delisting tahun 2011 - 2015 dari Bursa Efek Indonesia.

Penelitian yang dilakukan oleh Aminian, et. al. (2016), Kutum (2015) menunjukkan bahwa model Altman dapat mengklasifikasikan perusahaan di beragam tingkat posisi keuangan. Penelitian Aghajani dan Jouzbarkand (2012) menggunakan metode regresi logistik, menunjukkan bahwa model Springate dan SAF mampu dijadikan model dalam menganalisis kebangkrutan dalam perusahaan. Penelitian Radha Ganesh Kumar dan Kishore Kumar (2012) terhadap analisis kebangkrutan menggunakan tiga model dalam analisis kebangkrutan yaitu Altman, Ohlson, dan Zmijewski dapat diambil kesimpulan bahwa model Ohlson merupakan alat prediksi terbaik dibandingkan dengan Altman dan Zmijewski. Imanzadeh, MaranJouri dan Sepehri (2011) melakukan penelitian dengan metode Springate dan Zmijewski menyimpulkan terjadi perbedaan signifikan antar dua metode tersebut, dan metode Springate merupakan model yang lebih konservatif dibandingkan metode Zmijewski.

Berdasarkan uraian variabel dan beberapa penelitian terdahulu, maka penulis menyajikan kerangka pemikiran penelitian yang dapat ditunjukkan pada Gambar 2 .

\section{METODE}

Objek penelitian ini adalah perusahaan yang dihapuskan pencatatan dari daftar perdagangan saham (delisting) di Bursa Efek Indonesia pada tahun 2011 - 2015. Penelitian ini bertujuan untuk mengetahui bagaimana prediksi kebangkrutan dengan menggunakan metode Altman Z-Score, Springate dan Zmijewski dalam menganalisis perusahaan yang telah delisting di Bursa Efek Indonesia periode 2011 - 2015. Berikut mengenai penjabaran konsep dari variabel yang digunakan dalam penelitian ini dapat dilihat pada Tabel 1 .

Jenis penelitian yang digunakan dalam penelitian ini adalah penelitian deskriptif dengan metode pengambilan sampel non-probability sampling dengan teknik purposive sampling. Teknik purposive sampling adalah teknik penentuan sampel dengan pertimbangan tertentu. Berikut ini kriteria penentuan sampel yang digunakan oleh penulis dalam penelitian dapat dilihat pada Tabel 2.

Berdasarkan kriteria pengambilan sampel yang telah ditentukan maka terpilih sembilan perusahaan delisting yang dapat dijadikan sampel penelitian yaitu: (1) New Century Development Tbk (PTRA), (2) Surya Intrindo Makmur Tbk (SIMM), (3) Katarina Utama Tbk (RINA), (4) Indo Setu Bara Resources Tbk (CPDW), (5) Indosiar Karya Media Tbk (IDKM), (6) Amstelco Indonesia Tbk (INCF), (7) Asia Natural Resources Tbk (ASIA), (8) Davomas Abadi Tbk (DAVO), (9) Bank Ekonomi Raharja Tbk (BAEK).
Melalui metode tersebut, dapat diperoleh gambaran dengan melakukan suatu analisis teori dari rasio keuangan. Penulis memperoleh data dari laporan keuangan setiap perusahaan yang diolah setelah itu dianalisis dan ditarik kesimpulan berdasarkan teori yang ada, sehingga dapat memberikan gambaran tentang keadaan keuangan perusahaan delisting di Bursa Efek Indonesia pada tahun 2011 - 2015, periode yang dijadikan acuan adalah laporan keuangan tiga tahun sebelum perusahaan delisting.

\section{HASIL}

Berdasarkan kriteria pengambilan sampel yang telah ditentukan maka terpiliha sembilan perusahaan delisting yang dapat dijadikan sampel penelitian dengan menggunakan acuan laporan keuangan tiga tahun sebelum perusahaan tersebut delisting dari Bursa Efek Indonesia. Masing-masing perusahaan dianalisis dengan menggunakan metode Altman Z-Score, Springate, dan Zmijewski yang dibahas pada tabel-tabel sebagai berikut

Metode Altman memiliki nilai cut off yang apabila nilai $Z>2,99$ maka perusahaan termasuk ke dalam kategori safe zone, yaitu area di mana perusahaan dikatakan sehat atau tidak bangkrut. Nilai $1,81<\mathrm{Z}<$ 2,99 maka perusahaan termasuk ke dalam kateori grey zone yang artinya perusahaan berada di daerah abu-abu yang bisa saja berpotensi bangkrut atau tidak bangkrut. Sedangkan apabila nilai $Z<1,81$ maka perusahaan termasuk ke dalam kategori distress zone dimana perusahaan memiliki potensi mengalami kebangkrutan. Pada Tabel 3 dapat dilihat satu tahun sebelum delisting, metode Altman menyatakan dari sembilan perusahaan yang delisting dari tahun 2011 - 2015, enam diantaranya masuk kategori distress zone yaitu perusahaan PTRA, RINA, CPDW, INCF, DAVO, dan BAEK karena nilai $\mathrm{Z}$ yang dihasilkan dari keenam perusahaan di bawah 1,81 , dua perusahaan IDKM dan ASIA masuk ke dalam kategori safe zone karena nilai $\mathrm{Z}$ pada kedua perusahaan berada diantara 1,81 dan 2,99, sedangkan satu perusahaan SIMM masuk ke dalam kategori grey zone karena memiliki nilai $\mathrm{Z}$ diatas 2,99. Pada hasil yang diberikan metode Altman, enam perusahaan yang diteliti yaitu PTRA, RINA, CPDW, INCF, DAVO, dan BAEK dinyatakan berada dalam distress zone dan telah di delisting dari BEI.

Metode Springate memiliki nilai cut off yang apabila $\mathrm{S}>0,862$ maka perusahaan masuk ke dalam kategori sehat atau tidak bangkrut, sedangkan apabila $\mathrm{S}<0,862$ maka perusahaan masuk ke dalam kategori bangkrut. Pada Tabel 4 dapat dilihat satu tahun sebelum delisting, metode Springate menyatakan dari sembilan perusahaan yang delisting dari tahun 2011 - 2015, enam diantaranya masuk kategori bangkrut yaitu perusahaan PTRA, SIMM, RINA, CPDW, ASIA dan BAEK karena keenam perusahaan memiliki nilai $\mathrm{S}$ dibawah 0,862 , dan tiga perusahaan IDKM, INCF dan DAVO masuk 
ke dalam kategori sehat karena memiliki nilai $\mathrm{S}$ diatas 0,862 . Pada hasil yang diberikan metode Springate, enam perusahaan yang diteliti yaitu PTRA, SIMM, RINA, CPDW, ASIA dan BAEK dinyatakan bangkrut dan telah di delisting dari BEI.

Cut off yang digunakan dalam metode ini adalah 0 dimana jika nilai $\mathrm{X}$ bernilai positif maka perusahaan masuk ke dalam kategori bangkrut. Sedangkan jika nilai $\mathrm{X}$ bernilai negatif maka perusahaan masuk ke dalam kategori sehat. Pada Tabel 5 dapat dilihat satu tahun sebelum delisting, metode Zmijewski menyatakan dari sembilan perusahaan yang delisting dari tahun 2011 - 2015, empat diantaranya masuk kategori bangkrut yaitu perusahaan PTRA, SIMM, INCF dan BAEK karena memiliki nilai $X$ diatas 0 (positif), dan lima perusahaan RINA, CPDW, IDKM, ASIA, dan DAVO masuk ke dalam kategori sehat karena memiliki nilai $\mathrm{X}$ dibawah 0 (negatif). Pada hasil yang diberikan metode Springate, enam perusahaan yang diteliti yaitu PTRA, SIMM, INCF dan BAEK dinyatakan bangkrut dan telah di delisting dari BEI.

Tabel 6 dapat dilihat prediksi kebangkrutan dari sembilan perusahaan delisting pada tahun $2011-2015$ dengan menggunakan ketiga metode kebangkrutan yaitu Altman Z-Score, Springate, dan Zmijewski bahwa setiap hasil dari masing-masing metode memprediksi kebangkrutan dan menghasilkan nilai Z, S atau X yang berbeda-beda tetapi terdapat dua perusahaan yang pada ketiga metode tersebut masuk ke dalam kategori bangkrut yaitu PTRA dan BAEK.

\section{PEMBAHASAN}

Hasil keseluruhan prediksi kebangkrutan dapat dikatakan bahwa perusahaan yang delisting itu tidak selalu berpotensi mengalami kebangkrutan karena bisa saja perusahaan delisting karena atas dasar keinginan perusahaan itu sendiri (voluntary delisting). Pada umumnya, perusahaan memilih untuk go private adalah karena perusahaan sudah dalam kondisi yang memiliki kinerja baik dan mampu menghasilkan kenaikan profit yang berkesinambungan. Seperti PT. Indosiar Karya Media Tbk (IDKM) yang menurut ketiga metode diatas mengalami kondisi perusahaan yang sehat atau tidak bangkrut tetapi melakukan delisting. Menurut bisnis. liputan6.com, IDKM melakukan delisting karena adanya penggabungan (merger) dua emiten media yaitu PT. Surya Citra Media Tbk (SCMA) dan PT. Indosiar Karya Media Tbk (IDKM). Dari penggabungan tersebut meningkatkan peluang bagi perusahaan untuk meningkatkan sinergi operasional dari dua stasiun televisi.

Metode Altman Z-Score memprediksi perusahaan yang berada pada kategori distress zone adalah PT. New Century Development Tbk (PTRA) pada tahun 2008 - 2010, PT. Surya Intrindo Makmur Tbk (SIMM) pada tahun 2009, PT. Katarina Utama Tbk (RINA) pada tahun 2010 - 2011, PT. Indo Setu Bara Resources Tbk (CPDW) pada tahun 2010 - 2012, PT. Amstelco Indonesia Tbk (INCF) pada tahun 2010 - 2012, PT. Davomas Abadi Tbk (DAVO) pada tahun 2011 - 2013 dan PT. Bank Ekonomi Raharja Tbk (BAEK) pada tahun 2012 - 2014. Sedangkan perusahaan yang berada pada kategori grey zone adalah PT. Surya Intrindo Makmur Tbk (SIMM) pada tahun $2010-2011$.

Metode Springate memprediksi perusahaan yang berada pada kategori bangkrut adalah PT. New Century Development Tbk (PTRA) pada tahun 2008 - 2010, PT. Surya Intrindo Makmur Tbk (SIMM) pada tahun 2010 - 2011, PT. Katarina Utama Tbk (RINA) pada tahun 2009 - 2011, PT. Indo Setu Bara Resources Tbk (CPDW) pada tahun 2010 - 2012, PT. Indosiar Karya Media Tbk (IDKM) pada tahun 2010 - 2011, PT. Asia Natural Resources Tbk (ASIA) pada tahun 2011 - 2013, PT. Davomas Abadi Tbk (DAVO) pada tahun 2012, dan PT. Bank Ekonomi Raharja Tbk (BAEK) pada tahun 2012 - 2014.

Metode Zmijewski memprediksi perusahaan yang berada pada kategori bangkrut adalah PT. New Century Development Tbk (PTRA) pada tahun 2010, PT. Surya Intrindo Makmur Tbk (SIMM) pada tahun 2009 - 2011, PT. Katarina Utama Tbk (RINA) pada tahun 2010, PT. Indo Setu Bara Resources Tbk (CPDW) pada tahun 2010 - 2011, PT. Indosiar Karya Media Tbk (IDKM) pada tahun 2011, PT. Amstelco Indonesia Tbk (INCF) pada tahun 2010 - 2012, PT. Davomas Abadi Tbk (DAVO) pada tahun 2011 - 2012 dan PT. Bank Ekonomi Raharja Tbk (BAEK) pada tahun $2012-2014$.

\section{KESIMPULAN}

Berdasarkan hasil dan pembahasan yang telah dilakukan dapat diambil kesimpulan bahwa terdapat perbedaan hasil prediksi kebangkrutan menggunakan metode Altman Z-Score, Springate, Zmijewski. Kebanyakan perusahaan yang delisting di BEI tahun 2011-2015 diprediksi bangkrut sedikitnya dari salah satu metode. Perusahaan perlu memiliki kinerja keuangan yang baik sehingga menarik minat investor. Perusahaan yang diprediksi bangkrut dengan salah satu metode menunjukkan hasil keuangan yang buruk sehingga delisting dari Bursa Efek Indonesia.

\section{DAFTAR PUSTAKA}

Aghajani, V. and Jouzbarkand, M., 2012. The Creation of Bankruptcy Prediction Model Using Springate and SAF Models. Journal of Accounting Research, 54, pp.6-8.

Altman, E.I., 1968. Financial ratios, discriminant analysis and the prediction of corporate bankruptcy. The journal of finance, 23(4), pp.589-609. 
Altman, Edward I., dan Hotchkiss, Edith. 2006. Corporate Financial Distress and Bankcruptcy: Predict and Avoid Bankcruptcy, Analyze and Invest in Distressed Debt. New Jersey: John Wiley \& Sons, Inc.

Aminian, A., Mousazade, H., dan Khoshkho, O. 2016. Investigate the Ability of Bankruptcy Prediction Models of Altman and Springate and Zmijewski and Grover in Tehran Stock Exchange. Vol 7, No. 4

Bursa Efek Indonesia. 2004. Peraturan Nomor I-I tentang Delisting \& Relisting Saham di Bursa, Bursa Efek Indonesia.

Imanzadeh, P., Maran-Jouri, M., dan Sepehri, P. 2011. A study of the Application of Springate and Zmijewski Bankcruptcy Prediction Models in Firms Accepted in Tehran Stock Exchange. Australian Journal of Basic and Applied Sciences, Vol. 5 No. 11.

Kumar, Radhar G. 2012. A Comparison Of Bankruptcy Models. International Journal of Marketing, Financial Service and Management Research. Vol. 1, No. 4.
Kutum, Imad. 2015. Predicting the Financial Distress of Non-Banking Companies Listed on the Palestine Exchange (PEX), Vol.6, No.1.

Purnajaya, Komang dan Merkusiwati, K. 2014. Analisis Komparasi Potensi Kebangkrutan Dengan Metode Z-Score Altman, Springate, dan Zmijewski Pada Industri Kosmetik yang Terdaftar di Bursa Efek Indonesia. Jurnal Akuntansi. Universitas Udayana. Vol 7 No.1

Springate, G.L., 1978. Predicting the possibility of failure in a Canadian firm: a discriminant analysis (Doctoral dissertation, Simon Fraser University.).

Zmijewski, M.E., 1984. Methodological issues related to the estimation of financial distress prediction models. Journal of Accounting research, pp.59-82. ekbis.sindonews.com [Diakses pada tanggal 12 Oktober 2016]

http://bisnis.liputan6.com/read/518236/merger-denganscma-saham-indosiar-delisting-dari-bei [Diakses pada tanggal 27 Februari 2017]

\section{LAMPIRAN}

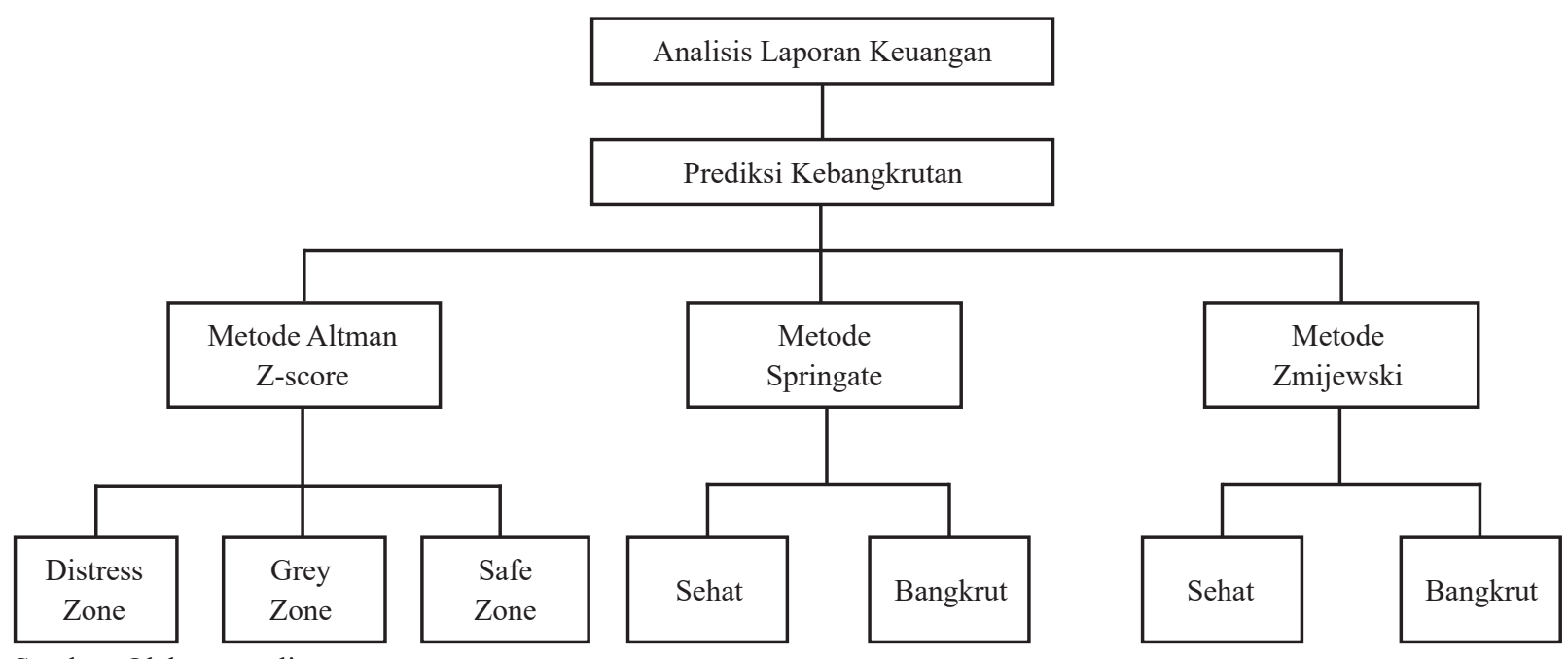

Sumber: Olahan penulis

Gambar 2. Kerangka Pemikiran Analisis Perusahaan Delisting di Bursa Efek Indonesia 
Tabel 1. Operasionalisasi Variabel

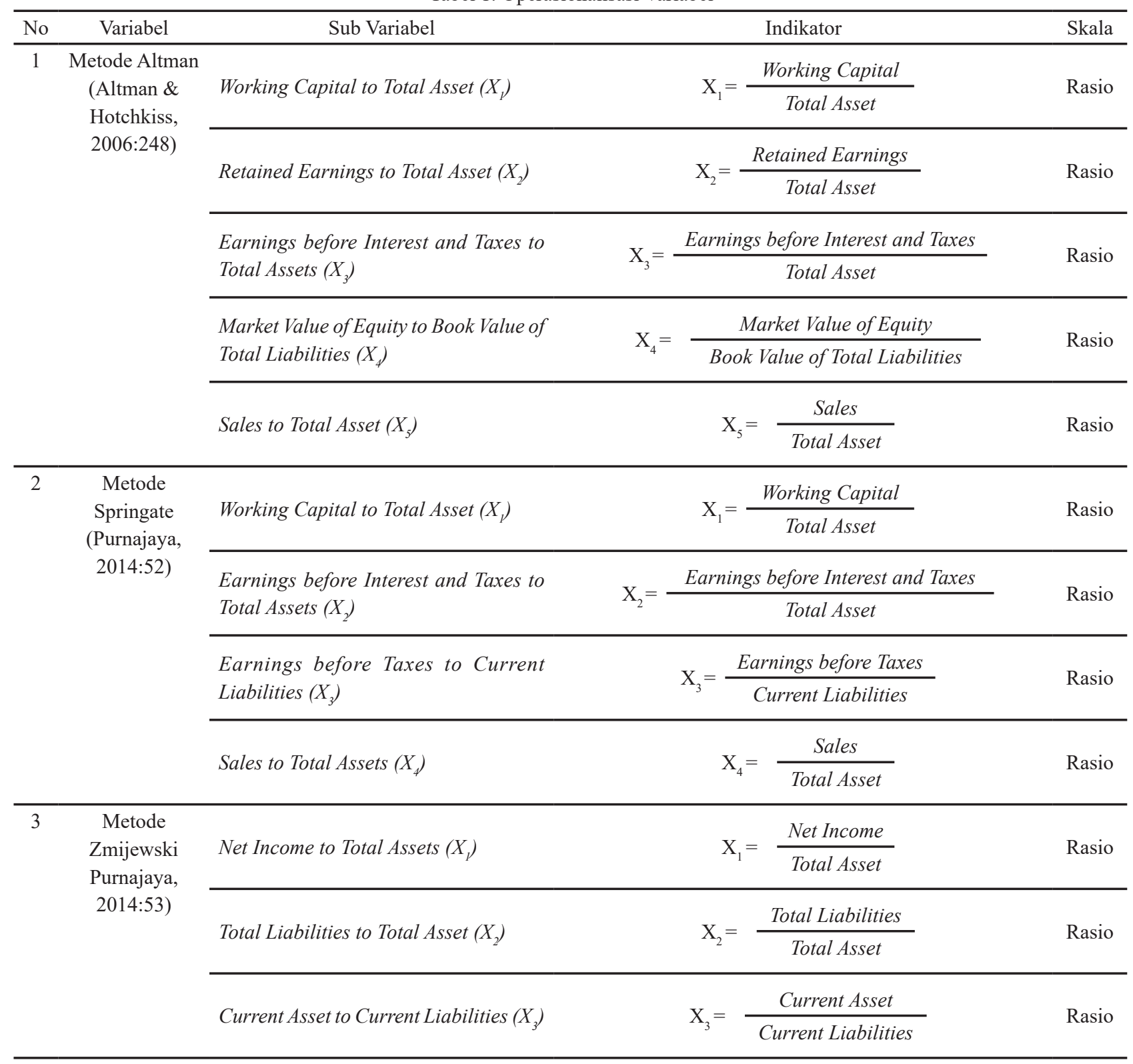

Tabel 2. Kriteria Pengambilan Sampel

\begin{tabular}{lc}
\hline Perusahaan yang delisting di Bursa Efek Indonesia pada tahun 2011-2015 & 20 \\
\hline Dikurang: & 9 \\
\hline Perusahaan yang tidak mempublikasikan laporan keuangan secara lengkap tiga tahun sebelum perusahaan delisting & 2 \\
Perusahaan yang laporan keuangannya tidak dapat diakses & 9 \\
\hline Total & \\
\hline
\end{tabular}


Tabel 3. Hasil Metode Altman pada Perusahaan Delisting Tahun 2011 - 2015

Periode Analisis Tahun 2008 - 2014

\begin{tabular}{|c|c|c|c|}
\hline Kode & Tahun & Z & Keterangan \\
\hline \multirow[t]{3}{*}{ PTRA } & 2008 & $-13,48$ & Distress Zone \\
\hline & 2009 & $-6,610$ & Distress Zone \\
\hline & 2010 & $-24,81$ & Distress Zone \\
\hline \multirow[t]{3}{*}{ SIMM } & 2009 & 1,738 & Distress Zone \\
\hline & 2010 & 2,888 & Grey Zone \\
\hline & 2011 & 2,670 & Grey Zone \\
\hline \multirow[t]{3}{*}{ RINA } & 2009 & 7,898 & Safe Zone \\
\hline & 2010 & $-3,692$ & Distress Zone \\
\hline & 2011 & 0,913 & Distress Zone \\
\hline \multirow[t]{3}{*}{ CPDW } & 2010 & $-0,404$ & Distress Zone \\
\hline & 2011 & $-6,447$ & Distress Zone \\
\hline & 2012 & $-3,453$ & Distress Zone \\
\hline \multirow[t]{3}{*}{ IDKM } & 2010 & 4,465 & Safe Zone \\
\hline & 2011 & 10,43 & Safe Zone \\
\hline & 2012 & 29,52 & Safe Zone \\
\hline \multirow[t]{3}{*}{ INCF } & 2010 & $-711,9$ & Distress Zone \\
\hline & 2011 & $-74,97$ & Distress Zone \\
\hline & 2012 & $-58,51$ & Distress Zone \\
\hline \multirow[t]{3}{*}{ ASIA } & 2011 & 3,577 & Safe Zone \\
\hline & 2012 & 4,197 & Safe Zone \\
\hline & 2013 & 4,993 & Safe Zone \\
\hline \multirow[t]{3}{*}{ DAVO } & 2011 & 0,993 & Distress Zone \\
\hline & 2012 & $-1,152$ & Distress Zone \\
\hline & 2013 & 1,037 & Distress Zone \\
\hline \multirow[t]{3}{*}{ BAEK } & 2012 & 0,395 & Distress Zone \\
\hline & 2013 & 0,453 & Distress Zone \\
\hline & 2014 & 0,456 & Distress Zone \\
\hline
\end{tabular}

Sumber: Data diolah oleh penulis
Tabel 4. Hasil Metode Springate pada Perusahaan Delisting Tahun 2011 - 2015

Periode Analisis Tahun 2008 - 2014

\begin{tabular}{|c|c|c|c|}
\hline Kode & Tahun & $\mathrm{S}$ & Keterangan \\
\hline \multirow[t]{3}{*}{ PTRA } & 2008 & 0,207 & Bangkrut \\
\hline & 2009 & $-0,237$ & Bangkrut \\
\hline & 2010 & $-158,8$ & Bangkrut \\
\hline \multirow[t]{3}{*}{ SIMM } & 2009 & $-1488,4$ & Bangkrut \\
\hline & 2010 & $-2125,4$ & Bangkrut \\
\hline & 2011 & $-2,703$ & Bangkrut \\
\hline \multirow[t]{3}{*}{ RINA } & 2009 & $-0,709$ & Bangkrut \\
\hline & 2010 & $-4,957$ & Bangkrut \\
\hline & 2011 & $-3,575$ & Bangkrut \\
\hline \multirow[t]{3}{*}{ CPDW } & 2010 & $-0,064$ & Bangkrut \\
\hline & 2011 & $-2,302$ & Bangkrut \\
\hline & 2012 & $-0,091$ & Bangkrut \\
\hline \multirow[t]{3}{*}{ IDKM } & 2010 & 0,736 & Bangkrut \\
\hline & 2011 & $-0,096$ & Bangkrut \\
\hline & 2012 & 2,565 & Sehat \\
\hline \multirow[t]{3}{*}{ INCF } & 2010 & -1749 & Bangkrut \\
\hline & 2011 & $-17,05$ & Bangkrut \\
\hline & 2012 & 1,315 & Sehat \\
\hline \multirow[t]{3}{*}{ ASIA } & 2011 & $-4,529$ & Bangkrut \\
\hline & 2012 & $-1,350$ & Bangkrut \\
\hline & 2013 & 0,081 & Bangkrut \\
\hline \multirow[t]{3}{*}{ DAVO } & 2011 & 1,232 & Sehat \\
\hline & 2012 & $-5349,2$ & Bangkrut \\
\hline & 2013 & 377,66 & Sehat \\
\hline \multirow[t]{3}{*}{ BAEK } & 2012 & 0,265 & Bangkrut \\
\hline & 2013 & 0,285 & Bangkrut \\
\hline & 2014 & 0,271 & Bangkrut \\
\hline
\end{tabular}

Sumber: Data diolah oleh penulis 
Tabel 5. Hasil Metode Zmijewski pada Perusahaan Delisting Tahun $2011-2015$

Periode Analisis Tahun 2008 - 2014

\begin{tabular}{|c|c|c|c|}
\hline Kode & Tahun & $\mathrm{X}$ & Keterangan \\
\hline \multirow[t]{3}{*}{ PTRA } & 2008 & $-0,638$ & Sehat \\
\hline & 2009 & $-0,357$ & Sehat \\
\hline & 2010 & 5,365 & Bangkrut \\
\hline \multirow[t]{3}{*}{ SIMM } & 2009 & 4,584 & Bangkrut \\
\hline & 2010 & 7,989 & Bangkrut \\
\hline & 2011 & 9,201 & Bangkrut \\
\hline \multirow[t]{3}{*}{ RINA } & 2009 & $-3,949$ & Sehat \\
\hline & 2010 & 10,056 & Bangkrut \\
\hline & 2011 & $-2,943$ & Sehat \\
\hline \multirow[t]{3}{*}{ CPDW } & 2010 & 0,077 & Bangkrut \\
\hline & 2011 & 2052,04 & Bangkrut \\
\hline & 2012 & $-0,046$ & Sehat \\
\hline \multirow[t]{3}{*}{ IDKM } & 2010 & $-0,474$ & Sehat \\
\hline & 2011 & 1,018 & Bangkrut \\
\hline & 2012 & $-2,459$ & Sehat \\
\hline \multirow[t]{3}{*}{ INCF } & 2010 & 1038,07 & Bangkrut \\
\hline & 2011 & 48,742 & Bangkrut \\
\hline & 2012 & 33,774 & Bangkrut \\
\hline \multirow[t]{3}{*}{ ASIA } & 2011 & $-2,061$ & Sehat \\
\hline & 2012 & $-2,028$ & Sehat \\
\hline & 2013 & $-2,427$ & Sehat \\
\hline \multirow[t]{3}{*}{ DAVO } & 2011 & 0,191 & Bangkrut \\
\hline & 2012 & 7,032 & Bangkrut \\
\hline & 2013 & $-8,469$ & Sehat \\
\hline \multirow[t]{3}{*}{ BAEK } & 2012 & 0,758 & Bangkrut \\
\hline & 2013 & 0,769 & Bangkrut \\
\hline & 2014 & 0,805 & Bangkrut \\
\hline
\end{tabular}

Sumber: Data diolah oleh penulis
Tabel 6. Hasil Keseluruhan Prediksi Kebangkrutan Metode Altman Z-Score, Springate, dan Zmijewski

\begin{tabular}{|c|c|c|c|c|}
\hline Kode & Tahun & Altman & Springate & Zmijewski \\
\hline \multirow[t]{3}{*}{ PTRA } & 2008 & Distress Zone & Bangkrut & Sehat \\
\hline & 2009 & Distress Zone & Bangkrut & Sehat \\
\hline & 2010 & Distress Zone & Bangkrut & Bangkrut \\
\hline \multirow[t]{3}{*}{ SIMM } & 2009 & Distress Zone & Bangkrut & Bangkrut \\
\hline & 2010 & Grey Zone & Bangkrut & Bangkrut \\
\hline & 2011 & Grey Zone & Bangkrut & Bangkrut \\
\hline \multirow[t]{3}{*}{ RINA } & 2009 & Safe Zone & Bangkrut & Sehat \\
\hline & 2010 & Distress Zone & Bangkrut & Bangkrut \\
\hline & 2011 & Distress Zone & Bangkrut & Sehat \\
\hline \multirow[t]{3}{*}{ CPDW } & 2010 & Distress Zone & Bangkrut & Bangkrut \\
\hline & 2011 & Distress Zone & Bangkrut & Bangkrut \\
\hline & 2012 & Distress Zone & Bangkrut & Sehat \\
\hline \multirow[t]{3}{*}{ IDKM } & 2010 & Safe Zone & Bangkrut & Sehat \\
\hline & 2011 & Safe Zone & Bangkrut & Bangkrut \\
\hline & 2012 & Safe Zone & Sehat & Sehat \\
\hline \multirow[t]{3}{*}{ INCF } & 2010 & Distress Zone & Bangkrut & Bangkrut \\
\hline & 2011 & Distress Zone & Bangkrut & Bangkrut \\
\hline & 2012 & Distress Zone & Sehat & Bangkrut \\
\hline \multirow[t]{3}{*}{ ASIA } & 2011 & Safe Zone & Bangkrut & Sehat \\
\hline & 2012 & Safe Zone & Bangkrut & Sehat \\
\hline & 2013 & Safe Zone & Bangkrut & Sehat \\
\hline \multirow[t]{3}{*}{ DAVO } & 2011 & Distress Zone & Sehat & Bangkrut \\
\hline & 2012 & Distress Zone & Bangkrut & Bangkrut \\
\hline & 2013 & Distress Zone & Sehat & Sehat \\
\hline \multirow[t]{3}{*}{ BAEK } & 2012 & Distress Zone & Bangkrut & Bangkrut \\
\hline & 2013 & Distress Zone & Bangkrut & Bangkrut \\
\hline & 2014 & Distress Zone & Bangkrut & Bangkrut \\
\hline
\end{tabular}

Sumber: Data diolah oleh penulis 